\title{
Effects of cutting height managements on yield and composition of different annual pastures
}

\section{Efeito do manejo sobre a produção e composição de diferentes pastagens anuais}

COMASSETO, Danielli dos Santos ${ }^{1}$

https://orcid.org/0000-0002-1963-9088

RODRIGUES, Carine Rey ${ }^{1}$

https://orcid.org/0000-0001-9017-5573

DORNELLES, Renata da Rosa ${ }^{1}$

https://orcid.org/0000-0001-6855-1720

FALEIRO, Eduardo Avelino ${ }^{1}$

https://orcid.org/0000-0001-7779-7618
PINTO, Augusto Gossmann ${ }^{1}$

https://orcid.org/0000-0002-5337-5709

CASTAGNARA, Deise Dalazen ${ }^{2}$

https://orcid.org/0000-0002-9143-305X

OAIGEN, Ricardo Pedroso ${ }^{2}$

https://orcid.org/0000-0002-5071-4170

DEL VALLE, Tiago Antonio ${ }^{1}$

https://orcid.org/0000-0001-8093-7132

AZEVEDO, Eduardo Bohrer de ${ }^{1 *}$

https://orcid.org/0000-0002-4541-8043

${ }^{1}$ Universidade Federal do Pampa, Campus Itaqui, Rua Luiz Joaquim de Sá Brito - Bairro Promorar, Itaqui - RS, 97650-000, Brasil

${ }^{2}$ Universidade Federal do Pampa, Campus Uruguaiana, BR 472 - Km 585 - Caixa Postal 118 Uruguaiana, RS - CEP 97501-970 RS, Brasil

*Mail for correspondence: ebazevedo@yahoo.com.br

\section{ABSTRACT}

This study aimed to evaluate the effects of different pre-cutting and residual heights of Pearl millet, Sudangrass, and Sorghum pastures on yield, morphological and chemical composition. The experimental design was the randomized blocks, with four experimental units per treatment. It was evaluated three species of forage: 1) Pearl millet (MIL; Pennisetum americanum); 2) Sudangrass (SUD; Sorghum sudanense); and 3) Sorghum (SOR; Sorghum bicolor); and two cutting managements: I) 50:20 - cutting height at $50 \mathrm{~cm}$ and $20 \mathrm{~cm}$ residual height; and II) $85: 10$ - cutting height at $85 \mathrm{~cm}$ and 10 $\mathrm{cm}$ residual height. Managements of cutting height affected neither forage yield per cut nor total forage yield. Sudangrass had less cuts than MIL and SOR when submitted to the 50:20 management. The 85:10 management increased stem proportion and leaf to stem ratio, and reduced leaf proportion in comparison with the 50:20 management. The 50:20 management reduced forage contents of fiber and organic matter, and increased forage contents of crude protein and total digestible nutrient. Sorghum exhibited greater nutritive value due to increased leaf proportion. The 50:20 management increased number of cuts and improved nutritive value of forages, regardless of species evaluated in this study. 
Keywords: Forage quality, Grassland, Intensive systems, Pastoralist strategies, Plant production.

\section{RESUMO}

Este estudo foi conduzido com o objetivo de avaliar os efeitos de diferentes alturas pré e pós colheita de milheto, capim-sudão e sorgo forrageiro sobre a produção de forragens e a composição morfológica e bromatológica. O experimento foi conduzido em delineamento em blocos casualizados, com quatro unidades experimentais por tratamento. Foram avaliadas três espécies forrageiras: 1) Milheto (MIL; Pennisetum americanum); 2) Capim-Sudão (SUD; Sorghum sudanense); e 3) Sorgo (SOR; Sorghum bicolor); e dois manejos de cortes: I) 50:20: com $50 \mathrm{~cm}$ de altura de corte e $20 \mathrm{~cm}$ de altura residual; e II) 85:10: com 85 e $10 \mathrm{~cm}$ de altura de corte e residual, respectivamente. Foram avaliados a produção, o número de cortes, e a composição morfológica e bromatológica. Não houve diferenças entre as espécies na produção por corte e na produção total, independentemente do manejo de cortes. O SUD apresentou menor número de cortes que MIL e SOR, quando submetido ao manejo 50:20. O manejo 85:10 aumentou a proporção de caule e a razão folha:caule em relação ao manejo 50:20. O manejo 50:20 reduziu os teores de fibra e matéria orgânica, enquanto aumentou os teores de proteína bruta e nutrientes digestíveis totais na forragem. O SOR tem um maior valor nutricional devido à maior proporção de folhas. $\mathrm{O}$ manejo 50:20 aumenta o número de cortes e o potencial nutricional, independentemente da espécie forrageira avaliada.

Palavras-chave: Estratégias pastoris, Pastagem, Produção vegetal, Qualidade de forragem, Sistemas intensivos.

\section{INTRODUCTION}

The global requirement for animal products has improved in recent years, which needs to be associated with biosecurity and economic standards, becoming a challenge to farmers. Forage and grassland systems must be productive, energy-efficient, reasonably priced, and resistant to stresses such as defoliation and drought. Different forages and managements, however, need to be evaluated to obtain forages with nutritive value that converges towards the animal production goals (HUNT et al., 2014).

In subtropical regions, such as the Southern region of Brazil, dry periods during the summer are frequent, compromising crop production (GOMES et al., 2015). Alternative forages such as Pearl millet [MIL; Pennisetum americanum (L.)] have been used to obtain a high forage yield [5.52 ton dry matter (DM) ha ${ }^{-1}$ per cut; MILKE et al. 2018]. Sorghum (SOR; Sorghum bicolor) and Sudangrass (SUD; Sorghum sudanense) have been used because of their resistance to low water availability (ZEGADA-LIZARAZU et al., 2012).

Pasture management is one of the main factors associated with production and nutritive value of forage. An excessive low residual height of pasture significantly reduces plant leaf proportion and animals' intake (AMARAL et al., 2013), and increases 
the length of growing period (MEZZALIRA et al., 2013). Evaluating the effects of different MIL managements on feeding behavior, Mezzalira et al. (2013) found that heights of 60 and $20 \mathrm{~cm}$ at pre- and postdefoliation improve forage intake of dairy cows. Fonseca et al. (2012) studied different pasture managements of SOR and found that herbage intake was increased using a management of $50 \mathrm{~cm}$ pre-grazing height and $20 \mathrm{~cm}$ residual height (i.e. $40 \%$ of the pre-grazing height).

Pacheco et al. (2019) observed that MIL pastures have greater canopy height and number of tillers, and lower senescence rate than SUD pastures, resulting in different nutritive value between species which can be even more altered if pastures are submitted to poor managements. However, to the best of our knowledge, there is no study evaluating differences in production and nutritive value of MIL, SOR, and SUD when pastures are submitted to different cutting height managements. Therefore, we hypothesized that annual tropical grasses have different production and quality. In addition, low sward height at pre-cutting and high residual height promote the nutritive value of MIL, SOR, and SUD. This study evaluated the differences between MIL, SOR, and SUD when managed with pre-cutting and residual heights of 85:10 and 50:20, respectively.

\section{MATERIALS AND METHODS}

The trial was performed in a commercial farm (Itaqui, Rio Grande do Sul State, Brazil; $29.2^{\circ} \mathrm{S}, 56.4^{\circ} \mathrm{E}$, and $56 \mathrm{~m}$ a.s.1.) from December 2015 to April 2016. The climate was humid sub-tropical (Cfa) according to the Köppen classification, and the soil is classified as plinthosol with the following characteristics: $\mathrm{pH}-$ $\mathrm{H}_{2} \mathrm{O}=5.4 ; \mathrm{pH}-\mathrm{SMP}=6 ; \mathrm{Ca}=5.2 \mathrm{cmolc}$ $\mathrm{dm}^{-3} ; \mathrm{Mg}=1.5 \mathrm{cmolc} \mathrm{dm}^{-3} ; \mathrm{P}=6.6 \mathrm{mg}$ $\mathrm{dm}^{-3} ; \mathrm{K}=48.6 \mathrm{mg} \mathrm{dm}^{-3}$; organic matter $=14 \mathrm{~g} \mathrm{~kg}^{-1}$; exchangeable aluminium $=$ $0.2 \mathrm{cmolc} \mathrm{dm}^{-3}$, and base saturation $=$ $61.4 \%$.

The experiment was performed as a randomized blocked design using a $3 \times 2$ factorial treatment arrangement with four experimental units per treatment. This study evaluated three species of forage: 1) Pearl millet [Pennisetum americanum (L.) BRS $1503^{\circledR}$, Embrapa]; 2) Sorghum (Sorghum bicolor 2501C; 3) Sudangrass (Sorghum sudanense BRS Estribo $^{\circledR}$, Embrapa); and two cutting height managements: I) 50:20 - cutting height at $50 \mathrm{~cm}$ and $20 \mathrm{~cm}$ residual height; and II) 85:10 - cutting height at $85 \mathrm{~cm}$ and $10 \mathrm{~cm}$ residual height. The harvest was performed when the sward height reached the one stablished in the management treatments. Harvesting management was maintained until plants reached senescence. Parcels had $1.36 \times$ $5.00 \mathrm{~m}$ and $0.34 \mathrm{~cm}$ spacing between lines. Fertilization was performed according to the Soil Chemistry and Fertility Commission (CQFS) - RS / SC (CQFS, 2004), using: I) a commercial fertilizer with $40 \mathrm{~g}$ of $\mathrm{N}, 280 \mathrm{~g}$ of $\mathrm{P}$, and $280 \mathrm{~g}$ of $\mathrm{K}$ per $\mathrm{kg}$ at $300 \mathrm{~kg} \mathrm{ha}^{-1}$, during the sowing; II) nitrogen (as urea) divided into three supplies at $200 \mathrm{~kg} \mathrm{ha}^{-1}$, after each cut.

Pasture sward height was weekly monitored in twelve points randomly selected within the plot using a sward stick (BARTHRAM, 1985). Forage fresh matter production was obtained using the weight of pasture sampled from each parcel: plants were harvested according 
to management height, and all the pasture was weighed using a $1 \mathrm{~g}$-sensitive scare (Mark R622 ${ }^{\circledR}$, Bel Equipamentos Analíticos, Piracicaba, Brazil). Then, subsamples were taken and dried in an oven at $55^{\circ} \mathrm{C}$ for $72 \mathrm{~h}$. After oven-dried, the morphological composition was evaluated by manual separation of leaf lamina, stem, inflorescence, and dead material. Samples dried at $55{ }^{\circ} \mathrm{C}$ were ground in a knives mill, and chemical composition was analyzed as follows: dry matter (DM) in an oven at $105^{\circ} \mathrm{C}$ (DM), ash by burning in an oven at 550 ${ }^{\circ} \mathrm{C}$ (AOAC method no. 22.010 and $7010)$, and crude protein $(\mathrm{CP} ; 6.25 \times \mathrm{N}$; Kjeldahl method; AOAC no. 2036, 1960 and no. 2049) according to AOAC (1975). Neutral detergent fiber (NDF), acid detergent fiber (ADF), and acid detergent lignin (ADL) were determined according to Goering and Van Soest (1970). The hemicellulose was calculated as the difference between NDF and ADF. Cellulose was estimated as the difference between ADF and ADL. The total digestible nutrient (TDN) was calculated according to Weiss (1993).

Productivity data were analyzed using PROC MIXED of SAS 9.4 using the following model:

$Y_{i j k}=\mu+S_{i}+M_{j}+S \times M_{i j}+b_{k}+e_{i j k}$ with $b_{\mathrm{k}} \approx N\left(0, \sigma_{b}^{2}\right)$ and $e_{i j k} \approx N\left(0, \sigma_{e}^{2}\right)$; where: $\mathrm{Y}_{\mathrm{ijk}}$ is the observed value of the dependent variable; $\mu$ is the overall mean; $S_{i}$ is the fixed effect of specie ( $i=$ 1 to 3$) ; M_{j}$ is the fixed effect of management ( $j=1$ and 2); $S \times M_{i j}$ is the interaction effect between previously defined fixed effects; $b_{k}$ is the random effect of blocks ( $k=1$ to 4$)$; $e_{i j k}$ is the experimental error; $N$ stands for Gaussian distribution; $\sigma_{b}^{2}$ and $\sigma_{b}^{2}$ are the variances associated with blocks and error, respectively.

Data of chemical and morphological composition were analyzed considering the following model:

$Y_{i j k l}=\mu+S_{i}+M_{j}+S \times M_{i j}+b_{k}+\omega_{i j k}+C_{l}$

$+e_{i j k l}$

with $b_{k} \approx N\left(0, \sigma_{b}^{2}\right), \omega_{i j k} \approx N\left(0, \sigma_{\omega}^{2}\right)$, and $e_{i j k l} \approx M V N(0, R)$; where: $Y_{i j k l}$ is the observed value of the dependent variable; $\mu$ is the overall mean; $S_{i}$ is the fixed effect of specie ( $i=1$ to 3 ); $M_{j}$ is the fixed effect of management $(j=1$ and 2); $S \times M_{i j}$ is the interaction effect between previously defined fixed effects; $b_{k}$ is the random effect of blocks ( $k=1$ to 4$) ; \omega_{i j k}$ is the experimental error; $C_{l}$ is the fixed effect of cut (ordinal harvest); $e_{i j k l}$ is the random experimental error; $N$ stands for Gaussian distribution; $\sigma_{b}^{2}$ and $\sigma_{\omega}^{2}$ are the variances associated with blocks and error, respectively; $M V N$ stands for multivariate analysis with normal distribution; $R$ is the matrix of variance and covariance due to repeated measures. Matrices $(\mathrm{CS}, \mathrm{CSH}$, AR, ARH, TOEP, TOEPH, ANTE, VC, FA, and UN) were evaluated and chosen according to the Bayesian method. For all analyses, it was considered 0.10 as the significance level. Effects of species and species $\times$ management were studied using the Fisher means test (LSD) at 0.05 level.

\section{RESULTS}

No differences $(P \geq 0.530)$ on forage yield per cut or total forage yield were observed among different species, regardless $(P \geq 0.490)$ of management (Table I). The 85:10 management increased $(P<0.001)$ the forage yield per cut without affecting $(P=0.282)$ the total forage yield when compared with the 
50:20 management. There was an interaction effect between specie and cutting management $(P=0.012)$ on number of cuts. Species had similar $(P>$ $0.05)$ number of cuts when managed at

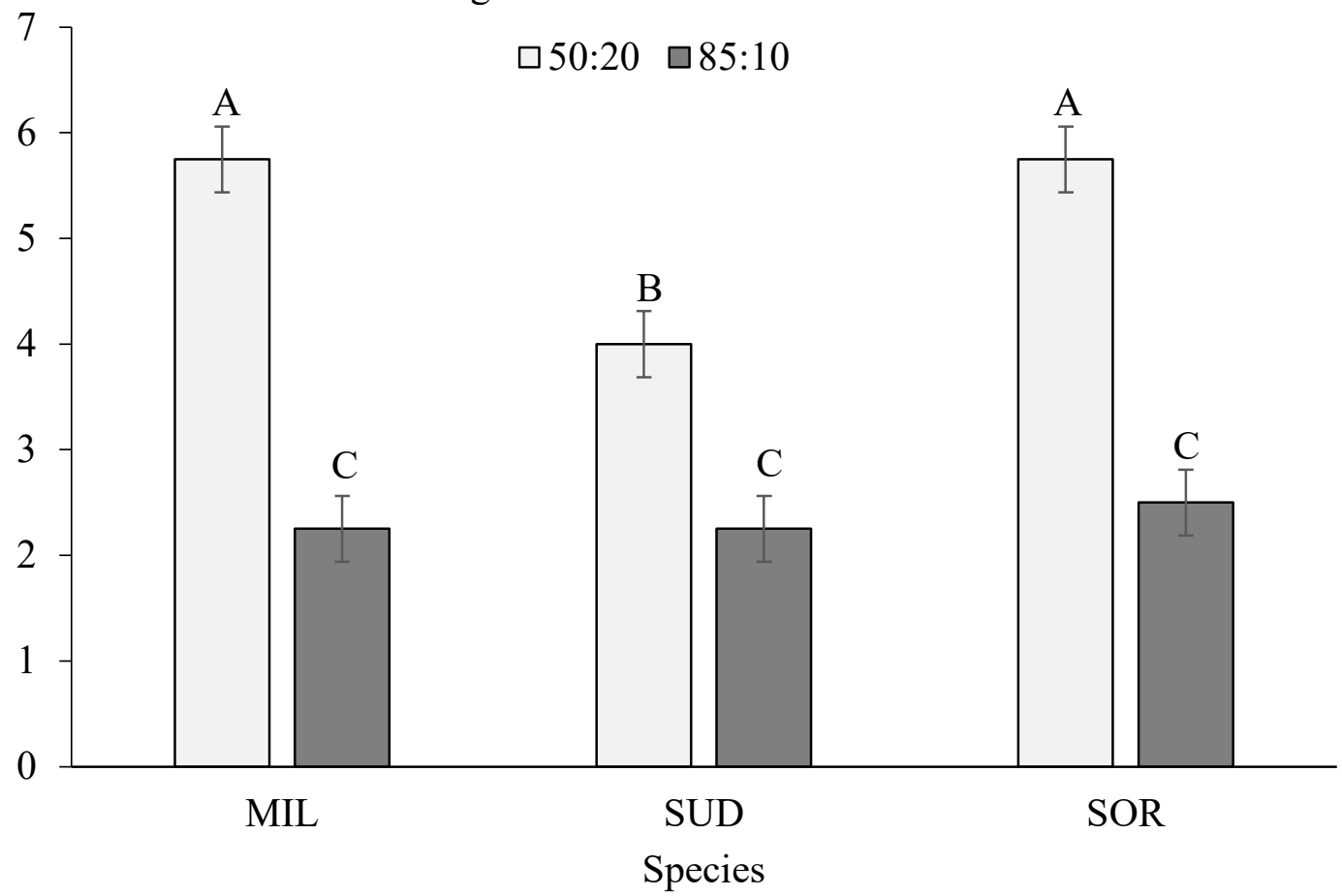

Figure 1. Number of cuts of tropical grasses submitted to different managements of cutting and residual heights

${ }^{\text {A-C }}$ Fisher means test (LSD) at $5 \%$ of probability.

${ }^{1}$ Species: Pearl millet (MIL; Pennisetum americanum (L.) BRS $1503^{\circledR}$, Embrapa); Sorghum (SOR; Sorghum bicolor 2501C); Sudangrass (SUD; Sorghum sudanense BRS Estribo ${ }^{\circledR}$, Embrapa);

${ }^{2}$ Managements: 50:20 - cutting height at $50 \mathrm{~cm}$ and $20 \mathrm{~cm}$ residual height; and 85:10 - cutting height at 85 $\mathrm{cm}$ and $10 \mathrm{~cm}$ residual height..

Error bars are SE.

There was an interaction effect between species and management $(P=0.095)$ for leaf proportion (Table II). At the 50:20 management, SUD reduced $(P \leq 0.05)$ leaf proportion compared to MIL and SOR (Figure 2). Using the 85:10 management, SOR had greater $(P \leq 0.05)$ leaf proportion than MIL and SUD. The 85:10 management increased plant proportions of stem $(P<0.001)$ and inflorescence $(P=0.097)$, and reduced $(P<0.001)$ leaf to stem ratio in comparison with the 50:20 management (Table II). Sorghum had a lower $(P \leq$ $0.05)$ stem proportion than MIL and SUD, and greater $(P \leq 0.05)$ leaf to stem ration compared to SUD. Pearl millet had greater $(P \leq 0.05)$ inflorescence proportion than SUD and MIL. 


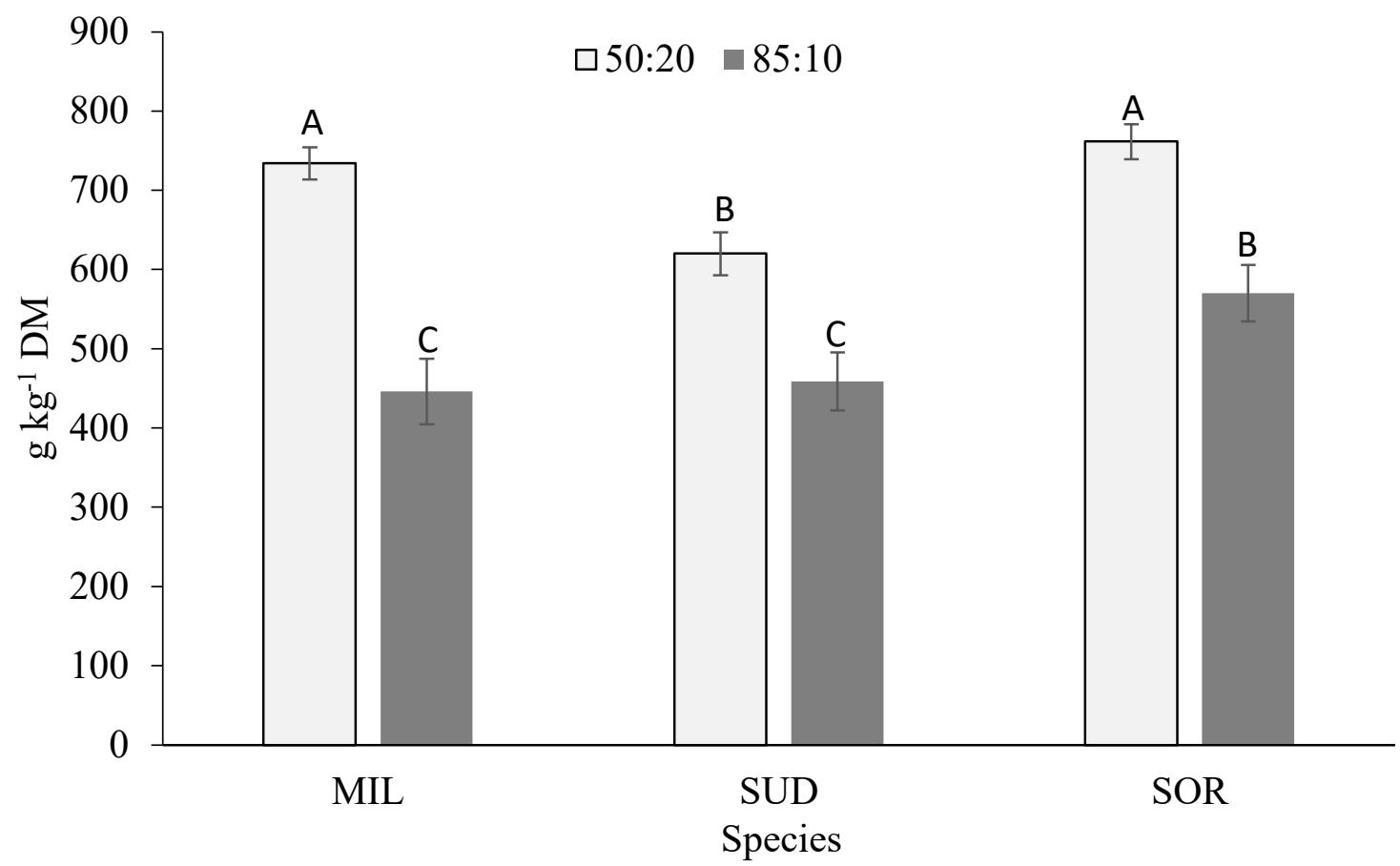

Figure 2. Leaf proportion of tropical grasses submitted to different managements of cutting and residual heights

A-C Fisher means test (LSD) at $5 \%$ of probability.

${ }^{1}$ Species: Pearl millet (MIL; Pennisetum americanum (L.) BRS $1503^{\circledR}$, Embrapa); Sorghum (SOR; Sorghum bicolor 2501C); Sudangrass (SUD; Sorghum sudanense BRS Estribo ${ }^{\circledR}$, Embrapa);

${ }^{2}$ Managements: 50:20 - cutting height at $50 \mathrm{~cm}$ and $20 \mathrm{~cm}$ residual height; and 85:10 - cutting height at 85 $\mathrm{cm}$ and $10 \mathrm{~cm}$ residual height.

Error bars are SE. 
Table 1.

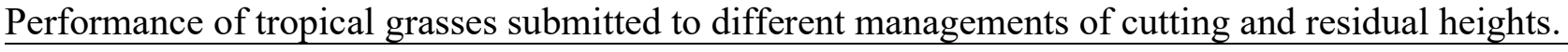

\begin{tabular}{|c|c|c|c|c|c|c|c|c|c|}
\hline \multirow{2}{*}{ Item } & \multicolumn{3}{|c|}{ Species $^{1}$} & \multicolumn{2}{|c|}{ Managements $^{2}$} & \multirow{2}{*}{$\mathrm{SEM}^{3}$} & \multicolumn{3}{|c|}{ Probabilities $^{4}$} \\
\hline & MIL & SUD & SOR & $50: 20$ & $85: 10$ & & SPE & MAN & SPE $\times$ MAN \\
\hline Number of cuts & 4.00 & 3.13 & 4.13 & 5.17 & 2.33 & 0.127 & 0.012 & $<0.001$ & 0.028 \\
\hline Yield per cut $\left(\mathrm{kg} \mathrm{DM} \mathrm{ha} \mathrm{ha}^{-1}\right)$ & 2173 & 2099 & 1955 & 1197 & 2954 & 162.5 & 0.858 & $<0.001$ & 0.490 \\
\hline Total yield (kg DM ha-1) & 6659 & 5728 & 6466 & 5896 & 6673 & 348.2 & 0.530 & 0.282 & 0.776 \\
\hline
\end{tabular}

${ }^{1}$ Species: Pearl millet (MIL; Pennisetum americanum (L.) BRS 1503 ${ }^{\circledR}$, Embrapa); Sorghum (SOR; Sorghum bicolor 2501C); Sudangrass (SUD; Sorghum sudanense BRS Estribo ${ }^{\circledR}$, Embrapa);

${ }^{2}$ Managements: 50:20 - cutting height at $50 \mathrm{~cm}$ and $20 \mathrm{~cm}$ residual height; and 85:10 - cutting height at $85 \mathrm{~cm}$ and $10 \mathrm{~cm}$ residual height;

${ }^{3}$ Standard error of the mean;

${ }^{4}$ Probabilities: effect of specie (MIL, SUD, and SOR); MAN (50:20 vs. 85:10); and SPE $\times$ MAN: specie and management interaction effect. 
Table 2.

Chemical and morphological composition of tropical grasses submitted to different managements of cutting and residual heights.

\begin{tabular}{|c|c|c|c|c|c|c|c|c|c|}
\hline \multirow{2}{*}{ Item } & \multicolumn{3}{|c|}{ Species $^{1}$} & \multicolumn{2}{|c|}{ Management $^{2}$} & \multirow{2}{*}{$\mathrm{SEM}^{3}$} & \multicolumn{3}{|c|}{ Probabilities $^{4}$} \\
\hline & MIL & SUD & SOR & $50: 20$ & $85: 10$ & & SPE & MAN & $\mathrm{SPE} \times \mathrm{MAN}$ \\
\hline \multicolumn{10}{|c|}{ Morphological composition, $\mathrm{g} \mathrm{kg}^{-1} \mathrm{DM}$} \\
\hline Leaf & $590^{\mathrm{B}}$ & $540^{\mathrm{B}}$ & $666^{\mathrm{A}}$ & 705 & 492 & 38.4 & $<0.001$ & $<0.001$ & 0.095 \\
\hline Stem & $378^{\mathrm{B}}$ & $443^{\mathrm{A}}$ & $323^{\mathrm{C}}$ & 281 & 481 & 12.4 & $<0.001$ & $<0.001$ & 0.285 \\
\hline Inflorescence & $24.3^{\mathrm{A}}$ & $6.79^{\mathrm{B}}$ & $5.65^{\mathrm{B}}$ & 7.30 & 17.2 & 2.862 & 0.010 & 0.097 & 0.153 \\
\hline Dead material & 6.51 & 5.55 & 5.66 & 4.67 & 7.14 & 1.622 & 0.872 & 0.146 & 0.592 \\
\hline Leaf to stem ratio & $1.56^{\mathrm{AB}}$ & $1.22^{\mathrm{B}}$ & $2.06^{\mathrm{A}}$ & 2.51 & 1.02 & 0.468 & 0.089 & $<0.001$ & 0.145 \\
\hline \multicolumn{10}{|c|}{ Chemical composition, $\mathrm{g} \mathrm{kg}^{-1} \mathrm{DM}$} \\
\hline Dry matter, $\mathrm{g} \mathrm{kg}^{-1}$ as-fed & $172^{\mathrm{B}}$ & $204^{\mathrm{A}}$ & $178^{\mathrm{B}}$ & 178 & 191 & 4.4 & 0.005 & 0.147 & 0.500 \\
\hline Neutral detergent fiber & $688^{\mathrm{AB}}$ & $709^{\mathrm{A}}$ & $678^{\mathrm{B}}$ & 678 & 705 & 5.8 & 0.062 & 0.031 & 0.304 \\
\hline Acid detergent fiber & 505 & 513 & 498 & 487 & 524 & 4.9 & 0.480 & 0.003 & 0.426 \\
\hline Cellulose & 402 & 403 & 389 & 376 & 420 & 4.7 & 0.307 & $<0.001$ & 0.563 \\
\hline Hemicellulose & 184 & 180 & 187 & 190 & 177 & 4.0 & 0.725 & 0.130 & 0.771 \\
\hline Lignin & $102^{\mathrm{C}}$ & $127^{\mathrm{A}}$ & $100^{\mathrm{B}}$ & 112 & 107 & 3.5 & 0.002 & 0.506 & 0.305 \\
\hline Crude protein & 152 & 140 & 159 & 175 & 126 & 5.4 & 0.298 & $<0.001$ & 0.257 \\
\hline Ash & $127^{\mathrm{A}}$ & $97.1^{\mathrm{C}}$ & $114^{\mathrm{B}}$ & 108 & 117 & 2.6 & $<0.001$ & 0.035 & 0.200 \\
\hline Total digestible nutrient & 523 & 516 & 529 & 538 & 508 & 6.3 & 0.579 & 0.017 & 0.459 \\
\hline
\end{tabular}

A-CFisher means test (LSD) at 5\% of probability;

${ }^{1}$ Species: Pearl millet (MIL; Pennisetum americanum (L.) BRS 1503 ${ }^{\circledR}$, Embrapa); Sorghum (SOR; Sorghum bicolor 2501C); Sudangrass (SUD; Sorghum sudanense BRS Estribo ${ }^{\circledR}$, Embrapa);

${ }^{2}$ Managements: 50:20 - cutting height at $50 \mathrm{~cm}$ and $20 \mathrm{~cm}$ residual height; and 85:10 - cutting height at $85 \mathrm{~cm}$ and $10 \mathrm{~cm}$ residual height;

${ }^{3}$ Standard error of mean;

${ }^{4}$ Probabilities: effect of specie (MIL, SUD, and SOR); MAN (50:20 vs. 85:10); and SPE $\times$ MAN: specie and management interaction effect. 
There was no interaction effect $(P \geq$ 0.200 ) between species and management for chemical composition of forage. The $85: 10$ management increased $(P \leq 0.035)$ forage contents of NDF, ADF, cellulose, and ash, and decreased $(P \leq 0.017)$ forage contents of $\mathrm{CP}$ and TDN. Sudangrass had greater $(P \leq 0.05) \mathrm{DM}$ content than SOR and MIL, and greater content of NDF than MIL. Yet, SUD had greater $(P \leq 0.05) \mathrm{ADL}$ content and lower $(P \leq 0.05)$ ash content than other species. Sorghum had lower $(P \leq 0.05)$ contents of ADL and ash than MIL.

\section{DISCUSSION}

There were no differences among the species on forage yield per cut and total forage yield. Orth et al. (2012) observed greater production when harvesting SOR hybrids compared with MIL. On the other hand, Jahansouz et al. (2014) observed that MIL had greater forage yield than SOR when submitted to water restriction, whereas Pacheco et al. (2014) reported no difference in forage yield between MIL and SUD when pastures were continuous grazed. Multiple environmental factors can affect pasture productivity and some of them can vary within the region of which pasture is evaluated (MUSSADIQ et al., 2012), which may provide inconclusive results. Ismail et al. (2018) evaluated the productivity of SUD and MIL under different conditions and crops showed similar productivity in normal conditions, whereas SUD had greater forage productivity under stressful conditions in comparison with MIL. The latter results suggest that the environmental conditions of the present study were not adverse.
The 85:10 management increased yield per cut compared with the 50:20 management. The lower residual height harms pasture regrowth in $\mathrm{C} 4$ species (FONSECA et al., 2012). Thus, is somewhat expected that the 85:10 management would present lower number of cuts compared with the 50:20 management, as pasture had a slower regrowth. The greater production per cut occurred because of the longer growth period required for the sward to reach 85 $\mathrm{cm}$ under the 85:10 management. A 10$\mathrm{cm}$ residual height removes most leaf area and apical meristems, often reducing organic reserves and tiller number (FONTANELI et al., 2001). Despite the 85:10 management reduced the number of cuts, no differences between managements were detected on total forage yield. According to Silva et al. (2015), there are three distinct phases during the regrowth curve: the first is characterized by an exponential increase in herbage mass, being highly influenced by environmental conditions and residual leaf area after cutting. During the second phase, constant rates of herbage accumulation are observed and the competition between plants become increasingly intense, mainly when the sward is close to the maximum canopy light interception; and in the third phase, there is a decrease in herbage accumulation rate as a consequence of leaf senescence. In the current study, the lack of management effect on total production could be associated with the canopy structure of plants: $95 \%$ of luminous interception might not have been reached even at the highest precutting height $(85 \mathrm{~cm})$.

An interaction effect between forage species and management was observed for the number of cuts. Sudangrass had 
less cuts than MIL and SOR when summited to the 50:20 management. Fontaneli et al. (2001) reported greater leaf proportion in MIL when compared to SUD cultivars. Similarly, Rodrigues et al. (2020) observed greater leaf to stem ratio in SUD than MIL. In the current study, we also observed lower leaf proportion when pastures were under the 50:20 management in SUD compared to MIL and SOR. Since leaf proportion and leaf area are major determinants for forage growth, SUD had lower number of cuts when managed at 50:20.

There were no differences among species on number of cuts when plants were submitted to the 85:10 management. Clapp and Chamblee (1970) studied the effects of different post-grazing residual heights on MIL and SUD managements. Authors observed that MIL has a regrowth more dependent on terminal buds and less dependent on tillering compared to SUD, because the basal and axillary tillering increased as the residual height of defoliation reduced from 25 to $8 \mathrm{~cm}$ for the SUD hybrids. In this study, the relatively high SUD dependence on tillering likely decreased the number of cuts when a sufficient number of terminal buds were provided (at 50:20 management), and no difference among species was observed using a lower residual height. Besides the greater tillering capacity of SUD, this forage species showed lower leaf proportion when compared to SOR, at the 85:10 management. According to Silva et al. (2015), the basal tillering improves the tiller population density, increases the canopy light interception, and anticipates senescence.

Sudangrass showed lower leaf proportion than SOR when managed at
85:10. Millner et al. (2011) reported cultivar effects on leaf to stem ratio, tiller density, and crop height at cutting. As SUD has an increased tillering capacity, plants were at the same height $(85 \mathrm{~cm})$, but SUD reached a more advanced physiological state. Several studies have reported increased stem and reduced leaf proportion in plants with an advanced phenological stage. According to Millner et al. (2011), increasing the grazing height increases the proportion of stem and leaves, and reduces the proportion of leaf mass in the upper extract. Similarly, Ferreira et al. (2018) reported increased tiller density and higher stem elongation after the first cut, as a consequence of competition for light.

Tomich et al. (2004) reported a negative correlation between plant height and leaf to stem ratio. Similarly, in the current study, the 85:10 management increased stem proportion and leaf to stem ratio, and reduced leaf proportion in relation to 50:20 management. Plants managed at $85: 10$ had greater stem percentage and lower leaf to stem ratio than those under the 50:20 management. The latter results are associated with changes in plant morphogenesis when cutting height is relatively high. The plant internode elongates when pasture is not cut at the appropriate sward height thus, increasing the proportion of steam and decreasing the proportion of leaf (TAIZ \& ZEIGER, 2010).

There was no interaction effect between specie and management on chemical composition of pasture. The 50:20 management reduced forage contents of NDF, ADF, cellulose, and ash, but increased contents of $\mathrm{CP}$ and TDN relative to $85: 10$ management. Leaf proportion affects the quality of forage, as leaves have greater protein content 
and lower fiber content than stem (BARRACLOUGH et al., 2014). Therefore, forages with greater leaf to stem ratio have improved nutritive value. According to Fontanelli et al. (2001), nitrogen fertilized MIL and SUD may reach the CP level of 127 to $178 \mathrm{~g} \mathrm{~kg}^{-1}$ $\mathrm{DM}$, close to values observed in the current study (from 140 to $159 \mathrm{~g} \mathrm{~kg}^{-1}$ DM). The lower fiber content of 50:20managed forages has a positive effect on TDN content of forage (WEISS, 1993); however, the differences in chemical composition among species were not sufficient to alter the results of TDN content. Further, the forage with the highest fiber content (SUD) had the lowest ash content. As TDN was calculated based on the organic matter, no differences were observed among species. It is unclear the reasons for differences in ash content of forages, once Tiritan et al. (2013) observed no difference in ash content between SOR and SUD.

In the current study, MIL had greater inflorescence proportion than SOR and SUD because of his heavier panicle compared to other species. The SOR showed greater leaf to stem ratio than SUD, which could be explained by the more developed genetic breeding programs which SOR has been submitted (KIKINDONOV et al., 2013). These results are reflected in lower NDF and ADL which are closely related to diet quality and livestock performance.

Sudangrass had greater proportion of leaves than SOR, evidencing a slow regrowth of SOR pasture. Sudangrass showed greater contents of DM, NDF, and ADL, and lower ash content than other species evaluated in this study. In addition, SOR had lower contents of ADL and ash than MIL. A technical extension note from university of Florida (NEWMAN et al., 2010) reported that the most efficient use of forage can be achieved when MIL reaches 50.8 to 63.5 $\mathrm{cm}$ height but the efficiency of forage use is jeopardized when the stubble height achieves 15.2 to $20.3 \mathrm{~cm}$. Therefore, the 50:20 management could be considered the ideal management for MIL.

Thus, SUD had lower leaf proportion and number of cuts than SOR and MIL when submitted to 50:20 management. The SOR had greater nutritional quality because of greater leaf to stem ratio, reflecting in lower fiber content. Regardless of species, the 50:20 management is superior than the $85: 10$ management because it improves the nutritive value of forage and enables a suitable distribution of forage for grazing.

\section{REFERENCES}

AMARAL, M.F.; MEZZALIRA, J.C.; BREMM, C. Sward structure management for a maximum short term intake rate in annual ryegrass. Grass and Forage Science v. 68, p.271-277, 2013.

ASSOCIATION OF OFFICIAL ANALYTICAL CHEMISTS. 1975. Official Methods of Analysis, 12th ed. Arlington, VA, USA.

BARRACLOUGH, P.B.; LOPEZBELLIDO, R.; HAWKESFORD, M.J. Genotypic variation in the uptake, partitioning and remobilisation of nitrogen during grain-filling in wheat. Field Crops Research, v.156, p.242248, 2014. 
BARTHRAM, G.T. Experimental techniques: the HFRO sward stick. In: HIFRO. The Hill Farming Research Organization Biennial Report 1984/1985. Penicuik: HFRO, 1985. p.29-30.

\section{COMISSÃO DE QUÍMICA E} FERTILIDADE DO SOLO RS/SC (CQFS RS/SC). 2004. Manual de adubação e calagem para estados do Rio Grande do Sul e Santa Catarina. SBCS/ NRS. 10. ed. Porto Alegre, 400 p.

CLAPP, J.G.; CHAMBLEE, D.S. Influence of different defoliation systems on the regrowth of pearl millet, hybrid sudangrass, and two sorghumsudangrass hybrids from terminal, axillary, and basal buds. Crop Science, v.10, p.345-349, 1970.

FERREIRA, E.A.; ABREU, J.G. de; MARTINEZ, J.C.; BRAZ, T.G.S.; FERREIRA, D.P. Cutting ages of elephant grass for chopped hay production. Pesquisa Agropecuária Tropical, v.48, n.3, p.245-253, 2018.

FONSECA, L.; MEZZALIRA, J.C.; BREMM, C.; FILHO, R.S.A.; GONDA, H.L.; CARVALHO, P.C.F.

Management targets for maximising the short-term herbage intake rate of cattle grazing in sorghum bicolor. Livestock Science, v.145, p.205-211, 2012.

FONTANELI, R.S.; SOLLENBERGER, L.E.; STAPLES, C.R. Yield, yield distribution, and nutritive value of intensively managed warm-season annual grasses.

Agronomy Journal, v.93, p.1257-1262, 2001.
GOERING, H.K.; VAN SOEST, P.J. Forage fibre analysis. Washington, DC: US Department of Agriculture. 1970.

GOMES, E.P.; RICKLI, M.E.; CECATO, U.; VIEIRA, C.V.; SAPIA, J.G.; SANCHES, A.C. Yield of Tifton 85 grass under irrigation and nitrogen doses. Revista Brasileira de Engenharia Agrícola e Ambiental, v.19, n.4, p.317-323, 2015.

HUNT, L.P.; MCIVOR, J.G.; GRICE, A.C.; BRAY, S.G. Principles and guidelines for managing cattle grazing in the grazing lands of northern Australia: stocking rates, pasture resting, prescribed fire, paddock size and water points - a review. The Rangeland Journal, v.36, n.2, p.105$119,2014$.

ISMAIL, S.M.; EL-NAKHLAWY, F.S;BASAHI, J.M. Sudan grass and pearl millets productivity under different irrigation methods with fully irrigation and stresses in arid regions. Grassland Science, v.64, n.1, p.29-39, 2018.

JAHANSOUZ, M.R.; AFSHAR, R.K.; HEIDARI, H.; HASHEMI, M.

Evaluation of yield and quality of sorghum and millet as alternative forage crops to corn under normal and deficit irrigation regimes Jordan Journal of Agricultural Sciences, v.10, n.4, p.699715, 2014.

KIKINDONOV, T.; KIKINDONOV, G.; SLANEV, K.; ENCHEV, S. Analysis of the green mass yield's structure of sudangrass and sorghum $\mathrm{x}$ sudangrass hybrids. Scientific Papers. 
Series A. Agonomy, v.56, p.296-297, 2013.

MEZZALIRA, J.C.; CARVALHO, P.C.F.; AMARAL, M.F.; BREMM, C.; TRINDADE, J.K.; GONÇALVES, E.N.; GENRO, T.C.M.; SILVA, R.W.S.M. Rotational grazing management in a tropical pasture to maximize the dairy cow's herbage intake rate. Arquivo Brasileiro de Medicina Veterinária e Zootecnia, v.65, n.3, p.833-840, 2013.

MILKE, L.M.; CAMPANA, M.; ANTONIO, G.; MORAIS, J.P.G.; ZILIO, E.M.C.; SANTOS, J.A.A.; DEL VALLE, T.A. Nutritional evaluation of millet at different seeding rates and cutting heights. Brazilian Journal of Veterinary Research and Animal Science, v.55, n.1, p.1-8., 2018.

MILLNER, J.P.; SILUNGWE, D.; MCGILL, C.R. Forage quality of sorghum, sudan-grass sorghum $\times$ sudangrass and pearl millet cultivars in Manawatu. Agronomy NZ Journal, v.41, p.13-22, 2011.

MUSSADIQ, Z.; HETTA,M.; SWENSSON, C.; GUSTAVSSON, A.M. Plant development, agronomic performance and nutritive value of forage maize depending on hybrid and marginal site conditions at high latitudes. Acta Agriculturae Scandinavica, v.62, n.5, p.420-430, 2012.

NEWMAN, Y.; JENNINGS, E.D.; VENDRAMINI, J.; BLOUNT, A. Pearl millet (Pennisetum glaucum): Overview and management. Florida Cooperative
Extension Service, University of Florida, USA. 2010.

ORTH, R.; FONTANELI, R.S.; FONTANELI, R.S.; SACCARDO, E. Forage yield of annual grasses seeded on the summer. Ciência Rural, v.42, n.9, p.1535-1540, 2012.

PACHECO, R.F.; BRONDANI, I.L.; BORCHATE, D.; MARINI, A.P.M.; MOURA, A.F.; RODRIGUES, L.S.; SILVA, M.A.; MAYER, A.R.; ALVES FILHO, D.C.; Morphogenesis of millet and sudangrass pastures subjected to continuous grazing. Boletim da Indústria Animal, v.76, p.1-7, 2019.

PACHECO, R.F.; ALVES FILHO, D.C.; BRONDAN, I.L.; NORNBERG, J.L.; PIZZUTI, L.A.D.; CALLEGARO, A.M. Productivity characteristics of sudan grass or pearl millet pastures submitted to continuous grazing by culling cows. Ciência Animal

Brasileira, v.15, n.3, p.266-276, 2014

RODRIGUES, C.R.; COMASSETTO, D.S.; DORNELLES, R.R.; ROSA, F.Q.; OAIGEN, R.P.; CASTAGNARA, D.D.; DEL VALLE, T.A.; AZEVEDO, E.B.; Production, bromatological, and phenological composition of tropical forage in the South Region of Brazil. Agrarian, v.13., n.47, p.82-92, 2020.

SILVA, S.C.; SBRISSIA, A.F.; PEREIRA, L.E.T. Ecophysiology of C4 forage grasses - understanding plant growth for optimising their use and management. Agriculture, v.5, n.3, p.598-625, 2015 
TAIZ, L.; ZEIGER, E. Plant physiology. Sinauer Associates, Sunderland, 782 p. 2010.

TIRITAN, C.S.; SANTOS, D.H.; MINUTTI, C.R.; FOLONI. J.S.S.; CALONEGO, J.C. Bromatological composition of sorghum, millet plant and midget-guandu at different cut times in intercropping and monoculture.

Acta Scientiarum - Agronomy, v. 35, p. 183-190, 2013.

TOMICH, T.R.; RODRIGUES, J.A.S.; ZOMICH, R.G.P.; GONCALVES, L.C.; BORGES, I. Forage. potential of sorghum sudangrass hybrids. Arquivo Brasileiro de Medicina Veterinária e Zootecnia, v.56, p.258-263, 2004.

WEISS, W.P. Predicting energy values of feeds. Journal of Dairy Science, v.76, n.6, p.1802-1811, 1993.

ZEGADA-LIZARAZU, W.; ZATTA, A.; MONTI, A. Water uptake efficiency and above- and belowground biomass development of sweet sorghum and maize under different water regimes. Plant and Soil, v.351, n.1-2, p.47-60, 2012. 